\title{
First Observation of Hb South Florida [beta 1(NA1) Val>Met] in Turkey
}

\section{Türkiye'de Gözlenen ilk Hb South Florida [beta 1(NA1) Val>Met] Olgusu}

\author{
Ayça Dilruba Aslanger1, Aynur Akbulut2, Gül Tokgöz³, Sakine Türkmen ${ }^{4}$, Kanay Yararbaş5 \\ ${ }^{1}$ Kocaeli Derince Training and Research Hospital, Medical Genetics Department, Kocaeli, Turkey \\ 2 Kocaeli Derince Training and Research Hospital, Department of Pediatrics, Kocaeli, Turkey \\ ${ }^{3}$ Kocaeli Derince Training and Research Hospital, Department of Hematology, Kocaeli, Turkey \\ ${ }^{4}$ Hemoglobinopathy Screening Center, Child, and Family Planning, Department of Health of Mother, Kocaeli, Turkey \\ ${ }^{5}$ Düzen Laboratory Group, İstanbul, Turkey
}

\section{To the Editor,}

Hemoglobin ( $\mathrm{Hb})$ South Florida [betal(NAl) Val>Met] is a rare beta hemoglobin variant that was first reported in 1985 from South Florida [1,2]. We report here, for the first time in Turkey, a 17-year-old female originally from Kars with $\mathrm{Hb}$ South Florida. She was referred to the Hemoglobinopathy Screening Center because of the history of thalassemia in some of her distant relatives. The variant was detected by high-performance liquid chromatography (HPLC) and confirmed with DNA sequencing. HPLC was performed with a Primus Ultra2 $\mathrm{Hb}$ variant analyzer (Trinity Biotech Dublin, Ireland) with the following results: $\mathrm{Hb}$ rate for $\mathrm{HbA0}$ 44\%, HbA2 3.2\%, spurious HbAlc peak (Acetyl Hb South Florida) $16 \%, \mathrm{Hb} \mathrm{X}_{1}$ (Hb South Florida 1) 26.3\%, $\mathrm{Hb} \mathrm{X}_{2}$ (Hb South Florida 2) 4.2\%, and HbAl (the sum of all $\mathrm{HbAl}$ forms including those with several minor peaks [range: $0.1 \%$ 3.4\%]) $6.3 \%$ (Figure 1). Red blood cell parameters were all in normal ranges, as follows: Hb $13.2 \mathrm{~g} / \mathrm{dL}$, Hct 38.5\%, RBC 4.8×1012/L, MCV $81 \mathrm{fL}, \mathrm{MCH} 27.7 \mathrm{pg}$, and MCHC $34.2 \mathrm{~g} /$ dL. HbAlc was shown to be 3.0\% with the Glycohemoglobin Analyzer's standard analysis mode (Tosoh Bioscience, Tokyo, Japan). DNA sequencing (ABI 3130 Genetic Analyzer, Applied Biosystems, Foster City, CA, USA) confirmed this Hb variant with a heterozygous mutation at the $\beta$-globin gene exon 1 codon 2 (c.4G>A, p.Val2Met, rs33395835, NG_000007.3). This mutation, next to the initiation codon, was named as codon 1 by the Huisman Database [betal(NA1) Val>Met] [3].

$\mathrm{Hb}$ South Florida was first reported in a Caucasian boy who had markedly elevated HbAlc (14.8\%) [1,2]. The detecting methods for HbAlc have the potential of detecting coexisting $\mathrm{Hb}$ variants or hemoglobinopathies. However, the HPLC techniques for HbAlc testing used in many hospitals are not designed for diagnosing $\mathrm{Hb}$ variants [4]. Thus, our case had a spuriously high HbAlc result of $16 \%$ in HPLC for variant hemoglobinopathy analysis mode, which measures acetyl $\mathrm{Hb}$, and HbAlc of 3\% in HPLC for standard analysis mode. Therefore, it is hard to identify this variant with a routine $\mathrm{HbAlc}$ measurement.

This hemoglobin variant in the heterozygous state does not produce any clinical symptoms. Only one other patient from Malaysia has been reported since the original report with a compound heterozygote mutation of c.4G>A (GTG>ATG) and IVS1-1 $(\mathrm{G} \rightarrow \mathrm{A})[5,6]$. Although the combination of $\mathrm{Hb}$ South Florida with $\beta$-thalassemia was found in the Malay with no associated clinical symptoms except hematological results consistent with the beta thalassemia trait, we knew that the

Address for Correspondence: Ayça Dilruba ASLANGER, M.D.,

Kocaeli Derince Training and Research Hospital, Medical Genetics Department, Kocaeli, Turkey

Phone: +90 2623178000 E-mail: aaslanger@yahoo.com

Received/Gelis tarihi : January 14, 2013

Accepted/Kabul tarihi : March 01, 2013 


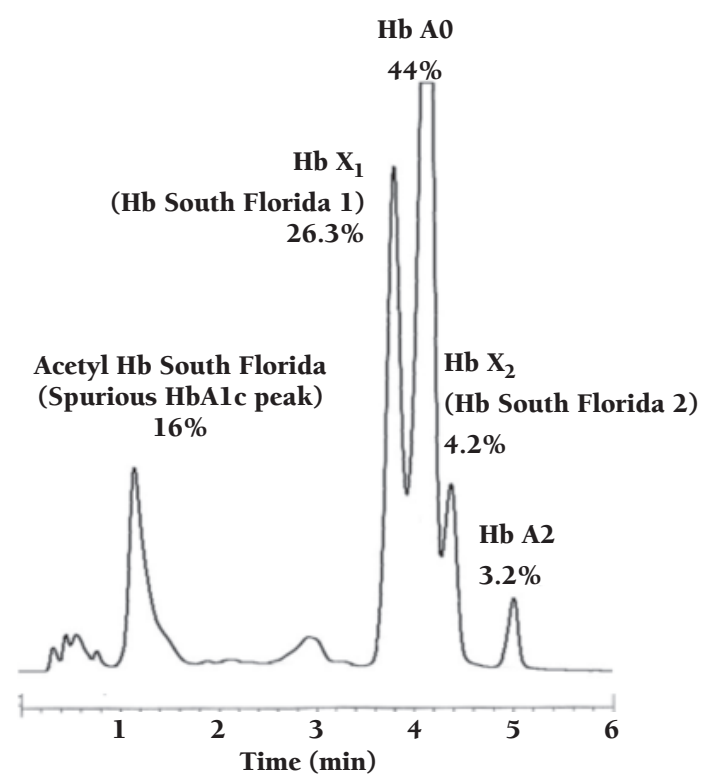

Figure 1: HPLC result of heterozygous Hb South Florida case.

interactions between 2 different $\mathrm{Hb}$ variants could result in more severe disease. This is especially important for countries like Turkey where the prevalence of the $\beta$-thalassemia carrier state and abnormal $\mathrm{Hb}$ is very high [7].

Key words: Abnormal hemoglobin, Hemoglobinopathy, HbAlc, Hb South Florida

\section{References}

1. Boissel JP, Kasper TJ, Shah SC, Malone JI, Bunn HF. Aminoterminal processing of protein: hemoglobin South Florida, a variant with retention of initiator methionine and $\mathrm{N}$-alphaacetylation. Proc Natl Acad Sci USA 1985;82:8448-8452.

2. Shah SC, Malone JI, Boissel JP, Kasper TJ. Hemoglobin South Florida. New variant with normal electrophoretic pattern mistaken for glycosylated hemoglobin. Diabetes 1986;35:1073-1076.

3. Huisman THJ, Carver MFH, Efremov GD. Hb South Florida. In: A Syllabus of Human Hemoglobin Variants (1996). Huisman Syllabus [database on the Internet]. The Sickle Cell Anemia Foundation, Augusta, GA, USA. Last accessed January 2013; available at http://globin.bx.psu. edu/cgi-bin/hbvar/query_vars3? mode=output $\&$ display_ format=page $\& i=713$.

4. Thomas LB, Agosti SJ, Man MA, Mastroides SM. Screening for hemoglobinopathies during routine hemoglobin Alc testing using the Tosoh G7 Glycohemoglobin Analyzer. Ann Clin Lab Sci 2007;37:251-255.

5. Tan JA, Chin PS, Wong YC, Tan KL, Chan LL, George E. Characterization and confirmation of rare beta-thalassaemias mutations in the Malay, Chinese and Indian ethnic groups in Malaysia. Pathology 2006;38:437-441.

6. Tan JA, Tan KL, Omar KZ, Chan LL, Wee YC, George E. Interaction of $\mathrm{Hb}$ South Florida (codon $1 ;$ GTG $\rightarrow$ ATG) and $\mathrm{HbE}$, with beta-thalassemia (IVS1-1; G $\rightarrow \mathrm{A}$ ): expression of different clinical phenotypes. Eur J Pediatr 2009;168:10491054.

7. Acemoglu H, Beyhun NE, Vancelik S, Polat H, Guraksın A. Thalassemia screening in a non-prevalent region of a prevalent country (Turkey): is it necessary? Public Health 2008;122:620-624. 